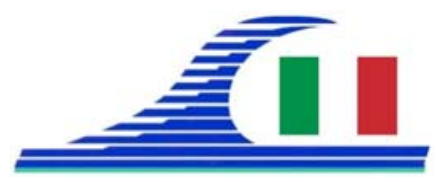

Conférence Méditerranéenne Côtière et Maritime EDITION 3, FERRARA, ITALIA (2015)

Coastal and Maritime Mediterranean Conference

Disponible en ligne - http://www.paralia.fr - Available online

\title{
A conceptual morphodynamic model including storm impacts for microtidal barred beaches
}

\author{
Mathieu GERVAIS ${ }^{1}$, Yann BALOUIN ${ }^{2}$, Raphaël CERTAIN ${ }^{3}$
}

1. Saint-Venant Hydraulics Laboratory (ENPC, EDF, Cerema), Université Paris-Est, Chatou, France.

Mathieu.gervais@laposte.net

2. BRGM, French Geological Survey, 1039 rue de Pinville, 34000 Montpellier, France.

Y.balouin@brgm.fr

3. CEFREM lab., University of Perpignan, 52 Av Paul Alduy, 66100 Perpignan, France. certain@univ-perp.fr

\begin{abstract}
:
This paper introduces the main results of a larger dataset concerning the impacts of storm events and recovery periods on a microtidal double barred beach of the NW Mediterranean Sea (Lido de Sète, Gulf of Lions, South France). The objective is to discuss the key control parameters among both the forcing conditions and the morphological state of the bar/beach system. Our new dataset (high frequency topobathymetries and ARGUS video) clearly demonstrates the importance of the morphological variations of the bar pattern along the beach. The steady alongshore irregularity of the outer bar depth and distance (maintained by some differences in the N.O.M.=Net Offshore Migration process) has a clear influence on the modal inner bar state and sensitivity of the bar and beach profile in response to storm events.

Keywords: Morphodynamics, Storm impacts, Erosion, Nearshore bar, Morphological coupling, Mediterranean Sea.
\end{abstract}

\section{Introduction}

A large number of recent publications deal with marine storm impacts on coastal morphologies (beach erosion, dune destructions...). Most examine the general hydrodynamic conditions (e.g.: ALMEIDA et al., 2012), with some others demonstrating the importance of the preexisting morphology (e.g. PRICE \& RUESSINK, 2011). But large uncertainty still remains on the respective role of the morphological state (i.e. position and shape of the nearshore bar before the storm; beach width and slope, ...) and the real influence of each parameter describing storm conditions (i.e. wind conditions; wave period and incidence; duration of the storm; water level, ...). 
Côtes méditerranéennes menacées :

Risques et défis dans le contexte du changement climatique

\section{Methodology and field site}

The effect of storm events and recovery periods were intensively surveyed during two winters (2008-2009 and 2009-2010) at the northern part of the Lido de Sète in the Gulf of Lions. Fifteen surveys of both the beach and shoreface were carried out before and after each storm to isolate the storms S1 to S8 from the recovery (calm) periods C1 to C4 (with some intermediate survey giving: C3.1, C3.2, ... ; GERVAIS et al., 2012). After one winter of less regular surveys, a 4th winter is then followed at very high frequency using a video monitoring system (BALOUIN et al., 2012).

Various kinds of storm characteristics were observed including: single or groups of storms; with short (rough wind seas) or longer period waves (swells); frontal or oblique waves; and $\mathrm{Hs}$ at the storm peak ranging from $3 \mathrm{~m}$ to $4.8 \mathrm{~m}$. Some smaller wave events were also isolated, as well as a very long period of calm during summer.

The site is representative of many of the Mediterranean beaches since it is exposed to a very irregular wave climate: very mild in average, but very intense during the winter storms $\left(H s_{\text {mean }}=0.7 \mathrm{~m}\right.$, but $H s_{1 \%}>3 \mathrm{~m}$ with marine winds $\left.>70 \mathrm{~km} / \mathrm{h}\right)$. Shoreface and nearshore bars morphology is not representative of the average wave height (ALEMAN et al., 2015), since the double bar system is only activate during the relative infrequent times of real wave action where there is breaking on the sandbars ( $10 \%$ of time).

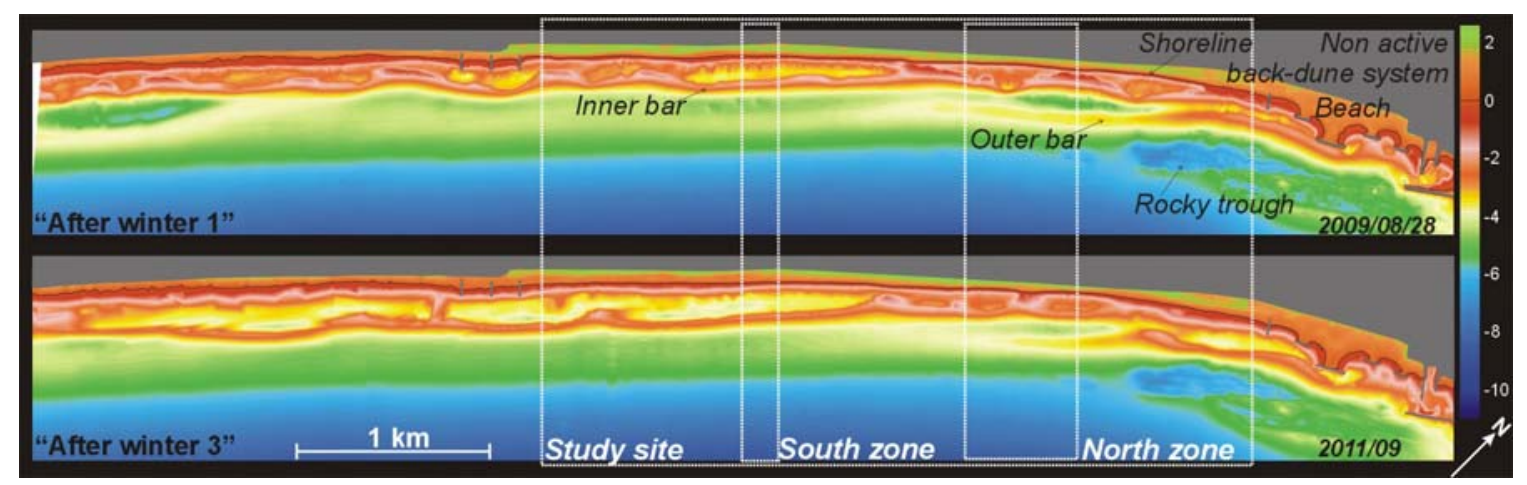

Figure 1. Example of multi-year conservation of the general aspect and distinction of bar patterns along the field site (and location of two high frequency survey areas).

\section{Results}

3.1 General conservation of the morphological state differences alongshore during four winters (low frequency evolution)

At the multi-year scale, as illustrated by the figure 1, despite the impact of several storm events, the nearshore bars noticeably preserve their alongshore variability. During the 4 years of the study, the inner bar is more rhythmic (several $\lambda \approx 500 \mathrm{~m}$ ) around the north zone of the study site, while remaining much more linear in the south (one $\lambda>1000 \mathrm{~m}$ ), therefore two zones have been designated for the high frequency surveys (figure 1). It 
just appears that the outer bar follows a degenerating process within the N.O.M. cycles which occurs in all the region (triggered by large storm events; GERVAIS et al., 2013). As a result, the inner bar generally retreats, noticeably losing a part of its rhythmic aspect (developing larger and flatter crescentic patterns). On the sub-aerial beach the longshore difference of bar morphology maintains two types of beachface-backshore profile during the 4 years (not shown), with a higher berm and a steeper beachface in the south (particularly obvious during storm events).

\subsection{The impact of storm and recovery period (high frequency evolution).}

The first objective was to define which hydrodynamic parameters prevail in the beach and shoreface response (GERVAIS et al., 2012 \& 2013). Our analysis demonstrates the foremost importance of significant wave height (Hs) at the storm peak. The storm duration, or total energy, has less influence on the typical storm behaviour (i.e. beach erosion, bar retreat) than the maximum power (height) reached by the wave peak. Essentially, the duration of the waning condition of the storm seems less significant, because the recovery process is then slower (seen in video data). Figure 2-A shows the importance of the Hs peak for longshore-uniform bar retreat, however, it demonstrates that multi-peak events (like the S8 storm group) or very oblique waves during a storm (like S6 or S5) may induce locally unusual bar displacement. Indeed, some large scale surveys show that the whole inner bar pattern may shift alongshore for a distance of $\sim 100 \mathrm{~m}$ in only few hours during storm (BALOUIN et al., 2012; GERVAIS et al., 2013). It also may displace large volume of sand in the mid-lower shoreface. The time in between storm during which small wave occur (like C1 to C4) is here the dominant factor to induce the onshore movement and recovery of the inner bar.

Concerning the rhythmic bar in the north of the site, the modifications not only depend on the storm intensity but also on the pre-existing morphology and on the wave direction. Video images (not shown here) shows that the small rhythmic bars ( $\lambda=200 \mathrm{~m}$ ) at the very north are much weaker and are easily reset (erased) by the storm fall, while the mid-scale $(\lambda=500 \mathrm{~m})$ crescentic patterns only partially straighten at the storm peak and then are able to recover with decreasing (or post-storm) conditions. But, some asymmetry may remain (skewed bar and rip channels) because of wave angle.

On average the beachface is eroded after almost every big wave event on both sites (south and north; figure 2-B) except when the wave period increases largely throughout the waning condition of the storm (for cases S4 and S7). We mainly demonstrate here that the Hs threshold for erosion, and the rate of change are not the same on both site (large rate in the south) and must depend on the protection given by the nearshore bars. In the south, it may be thought that the swash zone must adapt to more variable wave conditions than in the north (higher range of $\mathrm{Hs}$ and $\mathrm{Tp}$ ). The data on beach change over all the field site at storm scale indicate that the beach may also suffer from erosion and accretion hotspots as a function of the longshore displacement of the crescentic bar 
Côtes méditerranéennes menacées :

Risques et défis dans le contexte du changement climatique

horns, that may push intense current against the beach during storm or create weak point for wave passing trough the rip channel (in addition to latter create beach cusps).
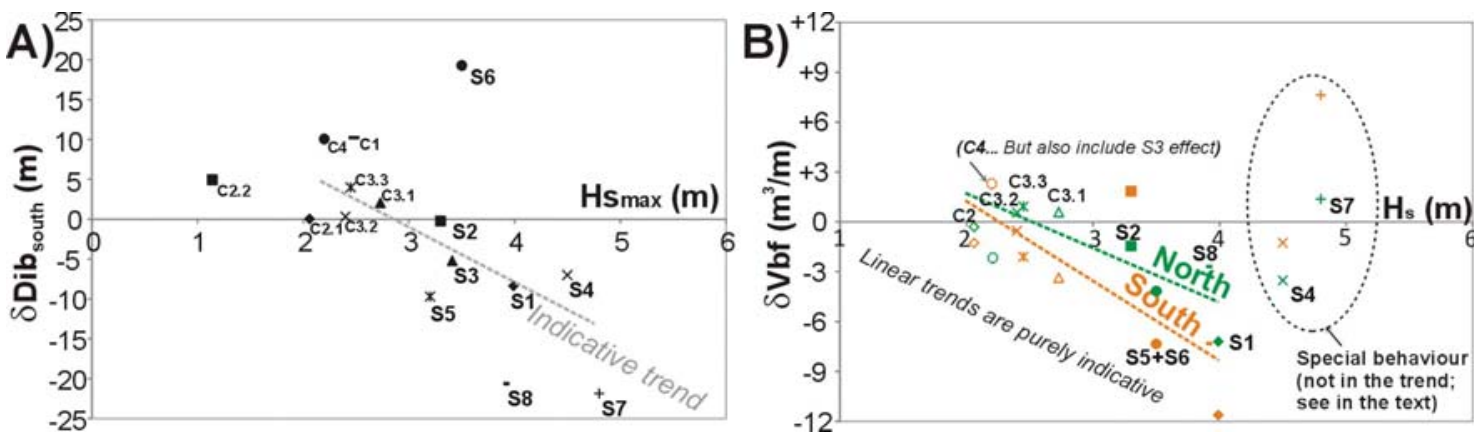

Figure 2. Influence of storm peak wave height on: A) the cross-shore displacements of the longshore uniform bar (positive = onshore and negative = offshore; here for the southern inner bar); and on B) the beachface volume change.

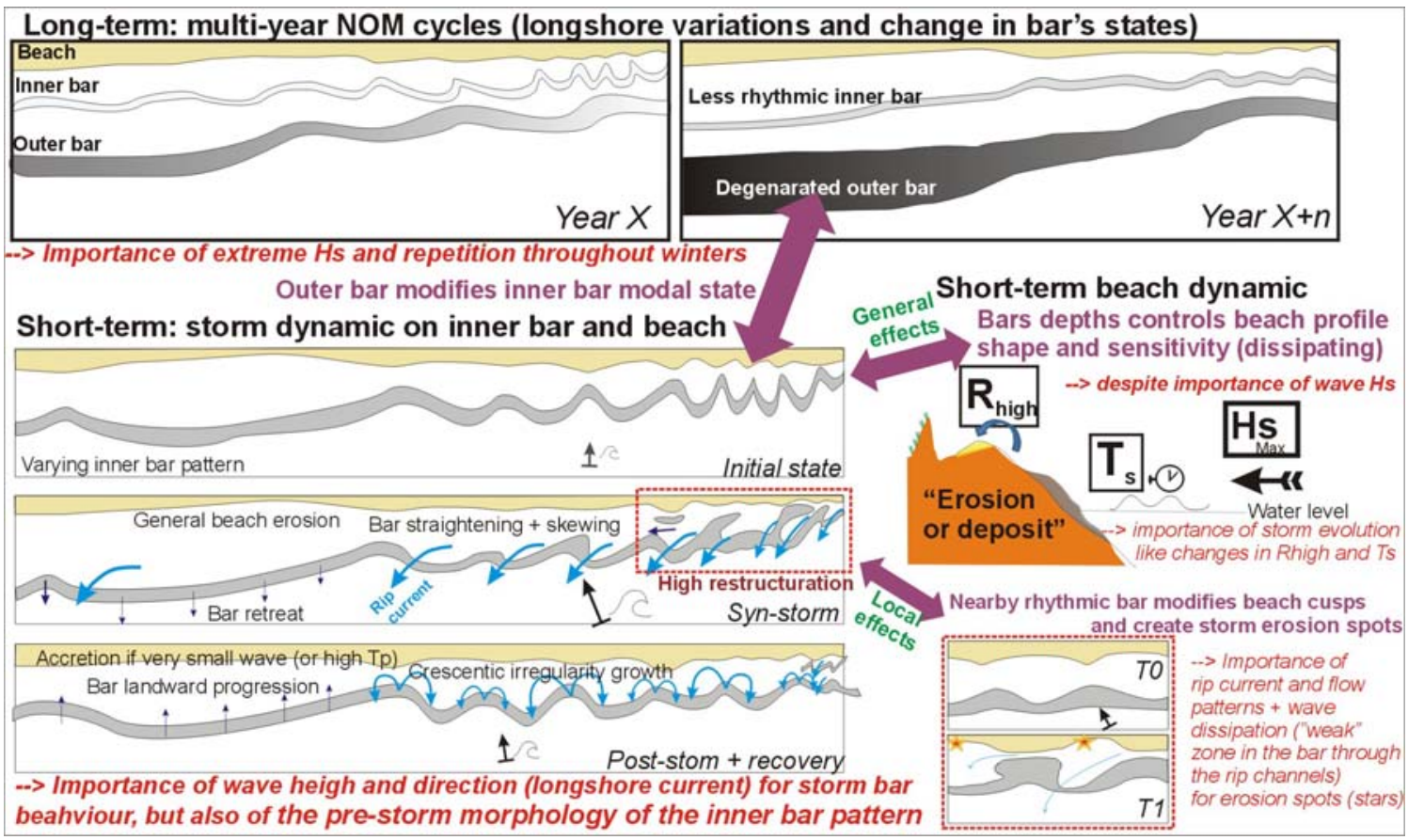

Figure 3. Conceptual model for the major control parameters of storm morphological evolution on a microtidal double barred beach with bar variations alongshore

\section{A conceptual model for the alongshore varying barred beaches}

A conceptual operating model of the beach morphodynamics in Sète is introduced in figure 3. This model gathers all the dominant factors involved in the storm morphological response of both the bar and sub-aerial beach system. We assume that this operating scheme could be extended to all the microtidal double- barred, intermediate to (storm) dissipative beaches where the bar varies alongshore (like 
Mediterranean coasts at threat:

Hazards and challenges in the context of climate variability

separate quite obliquely from the shore, for e.g.: ARMAROLI \& CIAVOLA, 2011), as well as in other environments with larger tides and more frequent wave action.

The influence of the inherited morphology relies on the bar's states. This influence involves two time scale (i) the long-term evolution of the outer bar within the N.O.M. multi-year trend that control the average (yearly) inner bar pattern (either distant and linear; or close and crescentic), and (ii) the short term storm evolution (and recovery), for which this ensuing longshore variations in the modal inner bar state (from variation in N.O.M.) determine locally the sensitivity of the bar itself (pattern robustness and cross-shore displacements) and the level of beach changes (like eroded volumes). At this short scale of a wave event, $H$ s thresholds are obviously essential, but the model shows the importance of the wave direction on sandbar dynamics (hence relative importance of longshore current). On the beach (to the right) it indicates the role of the wave run-up height for backshore dynamics, involving waves and morphologies criteria, as well as the interesting role of the wave period on the waning storm for beach recovery for future researches. The bottom right-hand corner of the model shows the significant bar-beach morphological feedback in places where the rhythmic inner bar move close to the beach which influences cusps but especially some erosion spots during the storms due to its effect on the wave dissipation and currents.

\section{References}

ALEMAN N., ROBIN N., CERTAIN R., ANTHONY E.J., BARUSSEAU J.P. (2015). Longshore variability of beach states and bar types in a microtidal, storm-influenced, low-energy environment. Geomorphology, Vol. 241, pp 175-191. http://dx.doi.org/10.1016/.j.geomorph.2015.03.029

ALMEIDA L.P., VOUSDOUKAS M.V., FERREIRA Ó., RODRIGUES B.A., MATIAS A. (2012). Thresholds for storm impacts on an exposed sandy coastal area in southern Portugal. Geomorphology, 143-144, pp 3-12. http://dx.doi.org/10.1016/j.geomorph.2011.04.047

ARMAROLI C., CIAVOLA P. (2011). Dynamics of a nearshore bar system in the northern Adriatic: A video-based morphological classification. Geomorphology, Vol. 126, pp 201-216. http://dx.doi.org/10.1016/.j.geomorph.2010.11.004

BALOUIN Y., DESBIENDRAS L., Gervais M., TESSON J. (2012). Dynamique à haute fréquence des barres d'avant-côte en milieu microtidal : suivi vidéo du Lido de Sète, Golfe du Lion (in French). XIIème Journées Nationales Génie Côtier, Génie Civil, Cherbourg, pp 169-178 . http://dx.doi.org/10.5150/jngcgc.2012.019-b

GERVAIS M., BALOUIN Y., BELON R. (2012). Morphological response and coastal dynamics associated with major storm events along the Gulf of Lions Coastline, France. Geomorphology, Vol. 143-144, pp 69-80. http://dx.doi.org/10.1016/j.geomorph.2011.07.035 
Côtes méditerranéennes menacées :

Risques et défis dans le contexte du changement climatique

GERVAIS M., BALOUIN Y., CERTAIN R. (2013). The major control parameters of storm morphological evolution on a microtidal barred beach. Proceeding of Coastal Dynamics Congress held in Arcachon, France 24-28 June 2013.

PRICE T.D., RUESSINK B.G. (2011). State dynamics of a double sandbar system.

Continental Shelf Research, Vol. 31, pp 659-674. http://dx.doi.org/10.1016/j.csr.2010.12.018 